\title{
Yemlik Tane Nohutun (Cicer arietinum L.) Kanatlı Rasyonlarında Kullanılma İmkânları
}

\author{
A. Yusuf ȘENGÜL ${ }^{1}$ (iD) Hakan İNCí1 ${ }^{(1 D)}$ Ömer SSENGÜL ${ }^{2}$ \\ ${ }^{1}$ Bingöl Üniversitesi, Ziraat Fakültesi, Zootekni Bölümü, Bingöl, Türkiye \\ ${ }^{2}$ Uludağ Üniversitesi, Ziraat Fakültesi, Zootekni Bölümü, Bursa, Türkiye \\ (*Sorumlu yazar e-mail: omersengul24@ hotmail.com)
}

DOI: 10.17097/ataunizfd.464457

Geliş Tarihi (Received Date): 27.09.2018

Kabul Tarihi (Accepted Date): 05.06.2019

\begin{abstract}
ÖZ: Dünyada ve ülkemizde çok eski yıllardan beri tarımı yapılmakta olan nohut, öncelikle insan beslenmesinde bitkisel kaynaklı protein ihtiyacının karşılanması bakımından önemlidir. Nohut, dünya bakliyat üretiminde kuru fasulyenin ardından ikinci sırada yer almaktadır. Yaklaşık olarak \%23 oranında ham protein içeren tane nohut, yüksek besleme değeri ile sadece insanlar için değil, hayvanlar için de önemli bir protein kaynağıdır. Yemlik tane nohut, kanatlı hayvanların protein ihtiyaçlarının karşılanmasında soya küspesinin yerine belirli düzeylerde kullanılabilme potansiyeli taşımaktadır. Ayrıca nohut, GDO’lu üretimi olmadığından özellikle organik kanatlı rasyonları çok önemli bir kaynak olabilir. Nohut, içerdiği besin maddelerinin yanı sıra çeşitli anti-besinsel faktörler de (proteaz inhibitörleri, amilaz inhibitörleri, lektinler, tanenler, oligosakkaritler) içermektedir (Çizelge 1). Nohudun içerdiği antibesinsel maddelerin etkisizleştirilmesi için genellikle, otoklavlama, pişirme, haşlama, ekstrüde etme, fermente etme ve mikrodalga ışınlara maruz bırakma gibi ssıl işlemlerin uygulanması önerilmektedir. Araştırmalarda, tane nohudun farklı ssıl işlemlere tabi tutularak kullanılmasıyla olumlu sonuçların alındığı bildirilmektedir. Bu derlemede, yemlik tane nohudun kanatlı hayvan beslemede kullanılma imkânları açıklanmaya çalıșılmıștır.
\end{abstract}

Anahtar kelimeler: Yemlik tane nohut, Kanatlı besleme, Anti-besinsel faktörler, Isıl işlem

Using Possibilities of Chickpeas (Cicer arietinum L.) in Poultry Diets

\begin{abstract}
The chickpea, cultivated in the world and in our country since very long years ago, is important in terms of meeting the need of plant-derived protein in human nutrition. With approximately $23 \%$ crude protein, chickpea with its high nutritional value is an important protein source not only for humans but also for animals. Chickpea may have potential at certain levels to replace of soybean meal to meet the protein requirements of poultry. Moreover, since chickpea is not GMO, in organic poultry diets are a very important source. It not only contains the nutrients but also contains various anti-nutritional factors (protease inhibitors, amylase inhibitors, lectins, tannins, oligosaccharides). In the case of chickpea joining on a certain level of ration as a raw, the anti-nutritional factors in question can negatively affect the health of poultry, especially. This negative effect limits consumption of raw chickpea. For this reason, it is recommended to apply heat treatments to neutralize the anti-nutritional substances contained in chickpea. These processes are usually autoclaving, cooking, scalding, extruding, fermenting and exposing to microwave. In researchers reported that positive results were obtained by using different heat treatments of chickpeas. In this review, it was discussed using possibilities of chickpea in poultry diets.
\end{abstract}

Keywords: Chickpea, Poultry nutrition, Anti-nutritional factors, Heat treatment

\section{GİRIŞ}

Diğer hayvancılık kollarında olduğu gibi kanatlı sektöründe de maliyetin yaklaşık \%70' ini yem girdileri oluşturmakla beraber, yem hammaddeleri arasında en yüksek fiyata sahip olanlar yüksek oranda protein içerenlerdir.

Kanatlı hayvanlarının beslenmesinde çok önemli bir yere sahip olan ve rasyondaki protein kaynağının temelini oluşturan soya açısından ülkemiz büyük ölçüde dışa bağımlıdır. 2016 yılında ülkemizde ihtiyaç duyulan soyanın yaklaşık \%7'si Türkiye'de üretilebilmiş, geri kalan kısmı ise (\%93) dış ülkelerden ithal edilmiştir. Gerek yurt içi tüketimin hızla artması ve gerekse büyük miktarlarda gerçekleşen ihracat nedeniyle, kanatlı sektörünün yem ihtiyacı her yıl artan miktarlarda yapılan soya küspesi ithalatı ile karşılanabilmiştir.

Kanatlı ürünlerdeki hızlı üretim artışı, doğal olarak kanatlı yemlerinde kullanılan soya küspesinin ithalatına da yansımıştır. Soya küspesinin GDO'lu olması uzun süreden beri önemli bir tartışma konusudur. GDO'lu soya küspesi içeren karma yemlerle beslenen hayvanlardan elde edilen ürünlerin insan tüketimine sunulması pek çok tüketiciyi tedirgin etmektedir. Yemde bulunan GDO'lu yem maddelerinin insan sağlı̆̆ı üzerine olası zararları üzerindeki çalışmaların yetersizliği, bu ürünlere alternatif oluşturabilecek veya en azından kullanımını azaltacak yem maddelerini gündeme getirmiştir.

$\mathrm{Bu}$ nedenle, gerek soya küspesindeki dişa bağımlılığın azaltılması, gerekse yerli üretimin desteklenmesi amaciyla, ülkemizde önemli miktarlarda üretilen alternatif yem kaynaklarının araştırılması zorunluluk haline gelmiştir. Bu konuda, ülkemizde önemli bir protein kaynağı ve öncelikle insan gidası olarak üretilen nohut ilk akla gelen bitkisel hammaddelerden biridir. Ribeiro and Melo (1990), kanatlı rasyonlarında nohut kullanılmasının ekonomik olması durumunda iyi bir alternatif protein kaynağı olabileceğini bildirmişlerdir. 
Tüm dünyada uzun yıllardan beri insan beslenmesinde önemli bir yer tutan nohut yaklaşık $\% 23$ ham protein, \%38 nişasta ve \%4.6 yă̆ içermektedir (Wang et al., 2010). Nohut, iyi bir protein ve karbonhidrat kaynağı olup, protein kalitesi diğer tahıllardan daha yüksektir (Kishor et al., 2017). Ayrıca, sahip olduğu yüksek sindirilebilirlik oranı (\%76-90) ile kanatlı rasyonlarında kullanılabilme potansiyeline sahiptir (Williams and Nakkoul, 1983). Bampidis et al. (2009), nohutun yumurta tavuklarının yemlerinde gerek büyüme, gerekse yumurtlama dönemlerinde protein ve enerji kaynağı olarak kullanılabileceğini bildirmişlerdir.

Ancak, tüm baklagiller gibi nohut ta, sağlığa zararlı etkileri olabilecek çeşitli-anti-besinsel faktörler (proteaz inhibitörleri, amilaz inhibitörleri, lektinler, tanenler, oligosakkaritler) içermektedir. Chavan et al. (1989), soya ve nohuttaki anti-besinsel faktör içeriğinin benzer olduğunu bildirmiştir. Cordesse (1990), bazı nohut varyetelerinin soya küspesinden 30-40 kat daha az anti-besinsel faktör içerdiğine ve bu varyetelerin rasyonda çiğ olarak kullanılmasının mümkün olduğunu bildirmiştir.

$\mathrm{Bu}$ anti-besinsel faktörler nohutun rasyonda çiğ olarak kullanımını sınırlamaktadır. $\mathrm{Bu}$ nedenle, nohuttaki anti-besinsel faktörlerin olumsuz etkilerinin azaltılması veya tamamen yok edilmesi amaciyla bazı işlemler uygulanmaktadır. $\mathrm{Bu}$ işlemler, öğütme, kırma, kavurma, suda haşlama, ıslatma, çeşitli kimyasal maddeler ile muamele etme, fermente etme ve çimlendirme gibi uygulamalardır. Bu işlemlerin, danenin sindirilebilirliğini arttırdığını ve çeşitli antibesinsel maddelerin inaktif hale geçmesini sağladığ birçok araştırıcı tarafından bildirilmiştir (Sharma and Nicholson, 1975; Deshpande and Cheryan, 1984; Deshpande and Damodaran, 1990; Van der Poel, 1990; Abdelgadir et al., 1996; Kaya ve Yalçın, 1999, Ertaş vd., 2008). Bampidis et al. (2009), tane nohutun içerdiği anti-besinsel faktörlerden tripsin ve kimotripsin inhibitörlerinin etkisini azaltmak ve proteinin sindirilebilirliğini arttırmak için 1sıl işlem uygulamasının etkili bir yöntem olduğunu bildirmiştir. Chavan et al. (1989) ve Saini (1989) farklı pişirme ve işleme yöntemleriyle nohuttaki anti-besinsel faktörlerin etkilerini azaltmanın mümkün olduğunu açıklamışlardır. Van der Poel (1989), baklagillerdeki anti-besinsel faktörlerin etkisizleştirilmesinde uygulanan 1sıl işlemlerden ekstrüzyonun çok iyi sonuç verdiğini bildirmiştir. Son yıllarda, gıda endüstrisinde 1sitma, kurutma, dondurulmuş halde kurutma, kavurma, firınlama, haşlama, pastörizasyon ve sterilizasyon gibi çeşitli amaçlar için kullanılan mikrodalga firınlar, anti-besinsel faktörlerin deaktivasyonu için de kullanılmaya başlanmıştır (Ercan vd., 1989; Mudgett, 1989; Özdemir vd., 2003).
Tane Nohutun Kanatlı Beslenmesinde Kullanımı Konusunda Yapılan Çalışmalar

Nohutun kanatlı hayvanların rasyonlarında hangi düzeylerde kullanılması gerektiği konusundaki çalışmalar henüz yetersizdir. Ancak, nohut çiğ olarak kanatlı rasyonlarında \%10-15 oranında, büyüme dönemindeki hindilerin ve yumurtacı tavukların rasyonlarında ise \%20 oranında kullanılabilmektedir (Jakob, 2015). Çiğ nohutun daha yüksek oranlarda kullanılması, canlı ağırlık kazancında yavaşlamaya, yumurta üretiminde azalmaya ve yemden yararlanmada kötüleşmeye neden olmaktadır (Jakob, 2015). Kanatlı rasyonlarında daha yüksek oranlarda nohut kullanılabilmesi, nohuta 1sıl işlem uygulanarak anti-besinsel faktörlerin etkisiz hale getirilmesi ile mümkün olabilmektedir (Jakob, 2015, Bampidis and Christodoulou, 2011). Cordesse (1990), nohutun ruminantlarda sınırsız olarak kullanılabileceğini, ancak kanatlılarda belirli bir kısıtlamanın olduğunu bildirmiştir.

Çizelge 1. Tane nohutun besin madde kompozisyonu (\%) ve içerdiği antibesinsel faktörler (Algam et al., 2012).

\begin{tabular}{|l|r|}
\hline Kompozisyon & Tane nohut \\
\hline Kuru madde & 93.100 \\
\hline Eter ekstrakt1 & 3.780 \\
\hline Ham protein & 24.310 \\
\hline Ham lif & 13.570 \\
\hline Kül & 3.022 \\
\hline Nitrojensiz ekstraktlar & 48.410 \\
\hline Tanen & 0.056 \\
\hline Polifenol & 0.030 \\
\hline Fitik asit & 0.641 \\
\hline Sindirilebilirlik & 83.380 \\
\hline Metabolik enerji $(\mathrm{kcal} / \mathrm{kg})$ & 2540.000 \\
\hline
\end{tabular}

\section{Etlik Piliçlerde Yapılan Çalışmalar}

Etlik piliçlerin rasyonlarında farklı düzeylerde çeşitli dane baklagiller kullanılarak yapılan bir çalışmada, rasyona denemenin 1. etabında \%50 oranında Kabuli cinsi nohut ve $\% 50$ oranında Maş fasulyesi, 2. etabinda ise $\% 20$ bezelye ve $\% 16$ oranında Desi cinsi nohut ilave edilmiştir. \%50 oranlarında Kabuli cinsi nohut ve maş fasulyesi içeren gruplar, kontrol grubuna oranla daha iyi canlı ağırlık artışı ve yemden yararlanma oranlarına sahip olmuşlardır. Kabuli cinsi nohut içeren grupta pankreas ağırlığı önemli düzeyde artış göstermiştir. \%20 oranında Desi cinsi nohut içeren grup ile \%16 oranında bezelye içeren gruplar, kontrol grubu ile karşılaştırıldığında, canlı ağırlık artışları ve pankreas ağırlıkları bakımından elde edilen değerler arasındaki farklılıkların önemsiz olduğu saptanmıştır. Desi cinsi nohut içeren grubun yemden yararlanma düzeyinin 
diğer gruplardan daha yüksek bulunduğu bildirilmiştir (Miller et al., 1991).

Etlik piliçlerin rasyonlarına yem bezelyesi, bakla, nohut ve tatlı lupin 6 farklı $(0,120,180,240$, 300 ve $360 \mathrm{~g} / \mathrm{kg}$ ) düzeyde ilave edilerek 3-6 haftalık dönemdeki besi performansları saptanmıştır. Hazırlanan rasyonların baklagil içeriklerinin yarısı soğuk $\left(45^{\circ} \mathrm{C}\right)$ yarısı sıcak $\left(70-80^{\circ} \mathrm{C}\right)$ peletlenmiştir. 021 günlük dönemde yem bezelyesi ve bakla, nohut ve tatlı lupin'e göre istatistiki olarak daha yüksek büyüme oranı ve daha iyi yemden yararlanma oranına sahip olmuşlardır. Büyüme oranı ve yemden yararlanma düzeyi rasyondaki bakla oranının artmasıyla iyileşme gösterirken, nohudun artmasıyla düşüş göstermiştir. Sicak peletleme, tüm gruplarda büyüme oranı ve yemden yararlanmayı olumlu yönde etkilemiştir. Nohut ile beslenen grupta pankreas ağırlığı önemli düzeyde artmıştır. Rasyona farklı düzeylerde baklagil ilavesi 21-42 günlük dönemde, etlik piliçlerin canlı ağırlık kazancı, yem tüketimi ve yemden yararlanma oranları arasında önemli bir farklılık oluşturmamıştır. Pankreas ağırlığı ise nohut içeren rasyonlarla beslenen piliçlerde önemli düzeyde yüksek bulunmuştur. Sıcak peletleme, bu dönemde de canlı ağırlık artışı ve yemden yararlanma düzeyi üzerine olumlu etkide bulunmuştur. Araştırmacılar, nohutun etlik piliçlerin beslenmesinde kullanılabileceğini bildirmişlerdir (Farrel et al., 1999).

Viveros et al. (2001), çiğ ve otoklavlanmış nohudun etlik piliç rasyonlarında kullanılmasıyla ilgili olarak yaptıkları bir çalışmanın ilk bölümünde, etlik piliçleri 0-28 gün boyunca $0,150,300$ ve $450 \mathrm{~g} / \mathrm{kg}$ düzeylerinde Kabuli cinsi çiğ nohut içeren rasyonlarla beslemişlerdir. Rasyondaki çiğ nohut miktarının artışı, canlı ağırlık kazancını, yem tüketimini, yemden yararlanmayı olumsuz yönde etkilemiş ve pankreas, karaciğer ve taşlık ağırlığını önemli derecede arttırmıştır. Araştırmacılar, çalışmanın ikinci bölümünde, 75 ve $150 \mathrm{~g} / \mathrm{kg}$ çiğ ve otoklavlanmış Desi cinsi nohut içeren rasyonlarla besleme yapmışlardır. Desi cinsi nohut içeren rasyonlarla beslenen gruplarda, canlı ağırlık kazancı ve yem tüketimi kontrol grubuna oranla daha düşük olmuştur. Rasyondaki nohut oranının artması, canlı ağırlık artışı, yem tüketimi ve yemden yararlanma düzeyi üzerine olumsuz etkide bulunmuştur. Çalışmanın ilk bölümü ile benzer şekilde, karaciğer ve pankreas ağırlığı önemli düzeyde artmıştır. Nohuda otoklavlama işleminin uygulanması, canlı ağırlık kazancı ve yem tüketimi üzerine olumlu etkide bulunmuş, fakat yemden yararlanmayı etkilememiştir. Otoklavlanmış Desi cinsi nohut içeren rasyonlarla beslenen etlik piliçlerde taşlık ve karaciğer ağırlıklarında önemli düzeyde düşme görülmüştür. Araştırmacılar, nohutun protein kaynağı olarak etlik piliçlerin rasyonlarında kullanılabileceğini bildirmişlerdir.
Nohut, çiğ olarak ve 1sıl işlemler uygulanarak 25 günlük yaştaki etlik piliçlerin rasyonlarına katılmış ve besi performansları araştırılmıştır. Etlik piliçler, iki farklı düzey ve 2 farklı muamele içeren 4 farklı rasyonla (120 kg/t çiğ nohut, $240 \mathrm{~kg} / \mathrm{t}$ çiğ nohut, 120 $\mathrm{kg} / \mathrm{t}$ 1sıl işlem görmüş nohut, $240 \mathrm{~kg} / \mathrm{t}$ 1sıl işlem görmüş nohut) soya küspesine ikame olarak beslenmişlerdir. $120 \mathrm{~kg} / \mathrm{t}$ çiğ ve $120 \mathrm{~kg} / \mathrm{t}$ 1sıl işlem görmüş nohut ile beslenen gruplarla kontrol grubu arasında, canlı ağırlık, yemden yararlanma oranı ve karkas verimi bakımından gözlenen farklılıklar önemli bulunmamıştır. Araştırmacılar, etlik piliçlerde soya küspesi yerine nohutun kesim ağırlığı, günlük yem tüketimi ve yemden yararlanma oranını etkilemeden $120 \mathrm{~kg} / \mathrm{t}$ 'a kadar kullanılabileceğini bildirmişlerdir (Christodoulou et al., 2006a).

Torki and Karimi (2007), soya küspesine ikame olarak nohut $(100 \mathrm{~g} / \mathrm{kg})$ kullanılan rasyonlara iki farklı ticari enzimin ilavesinin etlik piliçlerin performansına etkisini araştırmışlardır. Çalışmada, rasyona nohut ilavesinin canlı ağırlık artışına, yem tüketimine ve yemden yararlanma oranına etkisinin olmadığ belirlenmiştir. Enzim içeren grupların canlı ağırlıklarında bir miktar iyileşme olmuş, ancak bu artış istatistiksel anlamda önemli bulunmamıştır. Araştırmacılar, etlik piliç rasyonlarında soya küspesi yerine $\% 10$ düzeyinden daha fazla çiğ nohut kullanılması durumunda performansın olumsuz yönde etkilendiğini bildirmişlerdir.

0-3 haftalık dönemde rasyona farklı düzeylerde çiğ ve ekstrüde edilmiş nohut ilavesinin $(100,200$ ve $300 \mathrm{~g} / \mathrm{kg}$ ) etlik piliçlerin besi performansı üzerine etkisinin araştırıldığı bir çalışmada, rasyondaki nohut içeriğinin artması, canlı ağırlık artışı, yem tüketimi, yemden yararlanma düzeyi üzerine önemli bir etki yapmazken, pankreas ve karaciğer ağırlığı ile duodenum, ileum, jejunum ve sekum uzunluğunu önemli ölçüde arttırmıştır. Ekstrüde edilmiş nohut içeren rasyonlar, çiğ nohut içerenlere göre ağırlık kazancını arttırmış, pankreas ağırlığını ise kısmen azaltmıştır. Rasyona 300 g/kg'a kadar nohut ilavesi etlik piliçlerin besi performansı üzerine olumsuz bir etkide bulunmamış, fakat bazı sindirim organlarında ağırlık artışına neden olmuştur (Brenes et al., 2008).

Rasyona 45 gün süreyle çiğ nohut ilavesinin, etlik piliçlerde besi performansı ve kan parametreleri üzerine etkisinin araştırıldığı bir çalışmada, \%5, 10 ve 15 oranlarında nohut içeren gruplar ile kontrol grubu arasında yem tüketimi ve kan parametreleri bakımından önemli farklılıklar bulunmamıştır. \%10 ve $\% 15$ oranında nohut içeren rasyonlarla beslenen gruplar canlı ağırlık kazancı, yemden yararlanma oranı, kesim öncesi ağırlık ve karkas randımanı bakımından kontrol grubu ile benzer sonuç vermişlerdir. \%5 düzeyinde nohut içeren grup, canlı ağırlık kazancı, kesim öncesi ağırlığı, yemden yararlanma düzeyi ve karkas ağırlığı bakımından 
kontrol ve muamele gruplarına oranla önemli derecede daha düşük değerler göstermiştir (Algam et al., 2012).

Mahjoub and Ahmed (2016), etlik piliçlerin beslenmesinde kullanmak amacıyla hazırladikları yer fistığ 1 kekinde farklı düzeylerde $(\% 0,15,30,45,60)$ ıslatılmış nohut kullanmışlar ve piliçlerde besi performansı, karkas özellikleri ve kan parametreleri gibi özellikleri incelemişlerdir. Altı haftalık besi periyodu sonunda deneme grupları arasındaki farklılıklar, canlı ağırlık yem tüketimi, canlı ağırlık kazancı, karkas ağırlığı, karkas randımanı ve iç organ ağırlıkları (karaciğer, barsak, taşlık ağırlı̆̆ı) bakımından önemsiz, yemden yararlanma oranı bakımından ise önemli bulunmuştur. En iyi yemden yararlanan grup \%30 ilaveli grup olurken en kötü yemden yararlanan grup \%60 ilaveli grup olmuştur. Araştırmacılar, tüm parametreler dikkate alındığında \%30 düzeyinin en iyi sonuç verdiğini bildirmişlerdir.

Katogianni et al. (2008), organik şartlarda ve 81 gün süreyle etlik piliçlerle yaptıkları besi çalışmasında, rasyonda soya küspesi yerine $\% 0$ (kontrol), $\% 50$ ve $\% 75$ düzeylerinde nohut kullanmışlardır. Çalışmada, etlik piliçlerin canlı ağırlık, yem tüketimi, yemden yararlanma, ölüm oranı ve karkas özelliklerini incelemişlerdir. Çalışmada, kontrol grubuna ait canlı ağırlık değerleri, yem tüketimi ve karkas ağırlığı diğer gruplara oranla önemli derecede yüksek bulunmuştur. Gruplar arasında yemden yararlanma bakımından önemli farklılıklar bulunmamıştır. Araştırmacılar, 81 günlük organik etlik piliç besisinde, rasyonda soya küspesinin yerine çiğ nohutun aşamalı olarak \% 75 oranına kadar kullanılabileceğini bildirmişlerdir.

\section{Yumurtacı Tavuklarla Yapılan Çalışmalar}

25 haftalık yaştaki yumurtacı tavuk rasyonlarına $250 \mathrm{~kg} / \mathrm{t}$ tatlı lupin, bakla, nohut ve yem bezelyesi ilavesi yapılan bir çalışmada, yumurta verimi bakımından yem bezelyesi, tatlı lupin ve nohut içeren rasyonlarla beslenen gruplar arasında istatistiki olarak önemli bir farklılık saptanmamıştır. Yumurta ağırlığ 1 bakımından gruplar arasındaki farklılıklar önemsiz bulunurken, yem tüketimi bakımından en düşük değerlere nohut ve bakla içeren gruplar sahip olmuştur. Rasyonda nohut kullanılması yumurtacı tavukların performansını etkilememiş, ancak pankreas ağırlığında artış meydana getirmiştir. Araştırmacılar, yumurtlayan tavukların rasyonlarına $250 \mathrm{~kg} / \mathrm{t}$ 'a nohut ilavesinin verim performansını olumsuz bir şekilde etkilemediğini bildirmişlerdir (Perez-Maldonado et al., 1999).

Jakob (2015), nohutun çiğ olarak yumurtac1 tavukların rasyonlarında $\% 20$ oranına kadar kullanılabileceğini, bu oranın arttırılması durumunda yemden yararlanmada ve yumurta veriminde azalmalar olduğunu, rasyonda daha yüksek oranlarda nohut kullanılabilmesi için 1sıl işlemlerin gerekli olduğunu bildirmiştir.

\section{Hindilerle Yapılan Çalışmalar}

Christodoulou et al., (2006b), Beyaz hindi rasyonlarına soya küspesi yerine nohudun kısmen ve tamamen kullanılmasının besi performansı ve karkas verimine etkisini araştırmışlardır. Hindiler 12 hafta süreyle çiğ ve ekstrüde edilmiş nohut ilave edilerek $(0$, 200, 400,600, $800 \mathrm{~kg} / \mathrm{t}$ ) hazırlanmış rasyonlarla beslenmişlerdir. Rasyona soya küspesine ikame olarak $200 \mathrm{~kg} / \mathrm{t}$ oranında ekstrüde edilmiş nohudun ilavesi, canlı ağırlık ve yemden yararlanma düzeyi bakımından soya küspesine benzer sonuç vermiştir. Ancak, rasyondaki ekstrüde edilmiş nohut düzeyinin artmasiyla, kontrol grubuna oranla canlı ağırlıkta önemli düzeyde (\%7.7) düşüş, yemden yararlanma oranında ise önemli düzeyde artış (\%14.9) gözlenmiştir. Hindilerin karkas özellikleri rasyondaki nohut düzeyinin artmasından önemli düzeyde etkilenmemiştir. Araştırmacılar, besiye alınan hindilerde ekstrüde edilmiş nohutun rasyondaki soyanın yerine protein kaynağı olarak 200 kg/t'a kadar kullanılabileceğini bildirmişlerdir.

Sulaiman (2017), besiye alınan hindilerle yaptığ 8 haftalık bir çalışmada, hayvanları iki farklı rasyonla beslemiştir. 1. rasyon: mısır-soya temelli (kontrol), 2. rasyon: soya ve misırın yerine, \%30 buğday, \%10 mercimek ve \%10 nohut kullanılarak hazırlanmıştır. Besi dönemi sonunda, canlı ağırlık bakımından elde edilen sonuçlar buğday, mercimek ve nohut içeren rasyonla beslenen grupta kontrol grubuna oranla daha yüksek olmuştur. Grupların yemden yararlanma oranları ise farklı rasyonlardan etkilenmemiştir.

Jakob (2015), nohutun çiğ olarak besiye alınan hindilerin diyetlerinde $\% 20$ oranına kadar kullanılabileceğini, bu oranın arttırılması durumunda büyümede yavaşlama ve yemden yararlanmada kötüleşme olduğunu, hindi rasyonlarında daha yüksek oranlarda nohut kullanılabilmesi için ısıl işlemlerin mutlaka gerekli olduğunu bildirmiştir.

\section{Bıldırcınlarla Yapılan Çalışmalar}

35 gün süreyle besiye alınmış bıldırcınların rasyonlarında yemlik dane nohudun çiğ ve pişmiş olarak kullanılabilme imkânlarının araştırıldığı bir çalışmada, bıldırcınlar \%60 oranında çiğ ve $\% 60$ oranında haşlanmış nohut ihtiva eden rasyonlarla beslenmişlerdir. Deneme sonu canlı ağırlığı ve canlı ağırlık artışı bakımından kontrol grubu ile haşlanmış nohut içeren grup arasında farklılık bulunmazken, çiğ nohut içeren grupta bir miktar iyileşme söz konusu olmuştur. Yem tüketimi bakımından ise, kontrol grubu ile çiğ nohut içeren yemle beslenen grup arasında benzerlik görülürken, haşlanmış nohut içeren grupta düşüş gözlenmiştir. Karkas ağırlığı bakımından elde edilen sonuçlar, kontrol ve haşlanmış nohut 
gruplarında benzerlik gösterirken, çiğ nohut içeren grupta bir miktar iyileşme gözlenmiştir. Grupların karkas ağırlıkları arasındaki farklılıklar istatistiksel anlamda önemli olmamıştır (Obregón et al., 2012).

Şengül (2016), yumurtlayan bildırcınların rasyonlarına 10 hafta süreyle, çĭ̆ veya farklı şekillerde (otoklavlama ve mikro dalga işlemi) işlenmiş ve farklı düzeylerde ( $\% 20$ ve $\% 40)$ nohut ilavesinin, canlı ağırlık, yem tüketimi, yemden yararlanma oranı, yumurta verimi, yumurta ağırlığı, yumurta iç ve dış kalitesi, bazı kan parametreleri, yumurta sarısı yağ asidi profili ve yumurta sarısı yağ oranı üzerine etkilerini araştırmıştır. Çalışmada, gruplara ait canlı ağırlık, yem tüketimi, yemden yararlanma oranı, yumurta verimi, yumurta ağırlığı, kabuk kalınlığı, kabuk ağırlığı, sarı ağırlığı, sarı rengi ve ak indeksi bakımından elde edilen ortalamalar arasındaki farklılıklar önemsiz bulunmuştur. Şekil indeksi, Haugh birimi ve sarı indeksi bakımından gruplar arasındaki farkl1l1klar önemli bulunmuştur. Ayrıca, deneme gruplarına ait elde edilen ortalamalar arasındaki farklılıklar, kan parametrelerinden ALT düzeyleri için çok önemli, yumurta sarısı yăg asitlerinden heptadekanoik asit, stearik asit, palmitoleik asit, oleik asit, gama-linolenik asit, tekli doymamış ve toplam doymamış yağ asitleri için önemsiz, linoleik asit, $\alpha$-linoleik asit ve toplam doymuş yağ asitleri için önemli, palmitik asit oranları için çok önemli bulunmuştur. Çalışmada, en iyi sonucun nohudun otoklavlanarak kullanılmasıyla elde edildiği ve yumurtacı bıldırcın rasyonlarına $\% 40$ düzeyinde otoklavlanmış nohut ilavesinin herhangi bir olumsuz etkiye sahip olmadığı bildirilmiştir.

\section{SONUÇ}

Tane nohut, çiğ olarak kanatlı rasyonlarında \%20 düzeyine kadar kullanıldığ zaman verimde önemli düşüşlere neden olmadan soya küspesi yerine kullanılabilmektedir (Bampidis and Christodoulou, 2011). Fakat, nohutun içerdiği anti-besinsel faktörler özellikle besiye alınan kanatıların sindirim organlarında (karaciğer, pankreas, taşlık, barsaklar) büyümeye neden olabilmektedir (Huisman and Van der Poel, 1989; Perez-Maldonado et al., 1999; Farrel et al., 1999; Brenes et al., 2008). Birçok araştırmac1 tane nohudun çeşitli ssıl işlemlerle muamele edildiği zaman bu sorunun büyük ölçüde ortadan kalktığını, rasyonda kullanılabilme oranının arttığını, vitamin ve mineral kayıplarının azaldığını bildirmişlerdir (Singh, 1988; Christodoulou et al., 2006a; Brenes et al., 2008; Şengül, 2016). Yapılan araştırma sonuçları, tane nohudun, haşlama, otoklavlama, pişirme, ekstrüde, mikro dalga vb. 1sıl işlemlere maruz birakıldığında kanatlı rasyonlarında $\% 20$ ve daha yüksek düzeylerde kullanılmasının mümkün olduğunu göstermektedir. Ancak, anti-besinsel faktörlerin nohutun kanatlı rasyonlarında kullanılmasını sınırlayan bir faktör olduğu bir gerçektir.

Organik kanatlı diyetlerinde GDO'lu soya küspesinin yerine kullanılabilmesi nohutun dikkati çeken diğer önemli bir yönüdür. Nohut, organik tavukçulukta kullanılabilecek önemli GDO'suz protein kaynaklarından biri olarak dikkati çekmekte ve bu amaçla kullanılabilme potansiyeline sahiptir.

Yemlik tane nohudun kanatlı sektöründe kullanılması, soya küspesi ithalatını ve buna paralel olarak yurt dışına çıkan döviz miktarını azaltarak ülke ekonomisine önemli katkı sağlayacaktır. Bunun yanısıra, ithal edilen GDO'lu soya miktarının azalması GDO'nun insan sağlığı üzerine muhtemel olumsuz etkilerini de azaltacaktır.

\section{KAYNAKLAR}

Abdelgadir, I.E.O., Morrill, J.L., Higgins, J.J., 1996. Effects of roasted soybeans and corn on performance and ruminal and blood metabolites of dairy calves. Journal of Dairy Science, 79: 465-474.

Algam, T.A., Atti, K.A.A., Dousa, B.M., Elawad, S.M., Elseed A.M.F., 2012. Effect of dietary raw chick pea (Cicer arietinum L.) seeds on broiler performance and blood constituents. International Journal of Poultry Science, 11 (4): 294-297.

Bampidis, V.A., Christodoulou, V., Nistor, E., Skapetas, B., Nistor, G.H., 2009. The use of chickpeas (Cicer arietinum L.) in poultry diets: a review. Lucrari Stiintifice-Zootehnie şi Biotehnologii, 42 (1): 323-330.

Bampidis, V.A., Christodoulou, V., 2011. Chickpeas (Cicer arietinum L.) in animal nutrition: a review. Animal Feed Science and Technology, 168: 1-20.

Brenes, A., Viveros, A., Centeno, C., Arija, I., Marzo, F., 2008. Nutritional Value of Raw and Extruded Chickpeas (Cicer arietinum L.) for Growing Chickens. Spanish Journal of Agricultural Research, 6: 537-545.

Chavan, J. K., Kadam, S. S., Salunkhe, D. K., 1989. Chickpea. In: Salunkhe, D. K., Kadam, S. S. (eds.): CRC Handbook of world food legumes: nutritional chemistry, Processing technology and utilization. Vol. I. CRC Press, Inc. Boca Raton, FL, USA. 247-288.

Christodoulou V., Bampidis V. A., Hučko, B., Iliadis C., Mudř́k, Z. 2006a. Nutritional value of chickpeas in rations of broiler chickens. Arch. Geflügelkunde, 70: 112-118.

Christodoulou, V., Bampidis, V. A., Hučko, B., Mudř́k, Z., 2006b. The use of extruded chickpeas in diets of broiler turkeys. Czech J. Anim. Sci., 51 (9): 416-423. 
Cordesse, R., 1990. Value of chickpea as animal feed. Ecole Nationale Superieure Agronomique Institut National De La Recherce Agronomique Chaire De Zootechnie, 9: 127-131.

Deshpande, S.S., Cheryan, M., 1984. Preparation and antinutritional characteristics of dry bean protein concentrates. Qual. Plant Foods for Human Nutrition, 34: 185-196.

Deshpande, S.S., Damodaran, S., 1990. Food Legumes: Chemistry and Technology, In: Advances in cereal science and technology, Ed.: Pomeranz, Y., Minnesota, U.S.A. Association of Cereal Chemists, pp. 147-241.

Ercan, B., Acar, J., Aşkın, O., 1989. Mikrodalgalar, Gıda Endüstrisinde Kullanım Alanları ve Mikroorganizmaların Üzerine Etkileri. Gıda, 14 (3): 141-148.

Ertaş, N., Türker, S., Bilgiçli, N., 2008. Çeşitli Proseslerin Baklagilin Besinsel ve Antibesinsel Öğelerine Etkisi. Türkiye 10. G1da Kongresi; 2123 Mayis, 2008, Erzurum, s: 475-478.

Farrell, D.J., Perez-Maldonado, R.A., Mannion, P.F., 1999. Optimum Inclusion of Field Peas, Faba Beans, Chick Peas and Sweet Lupines in Poultry Diets. II. Broiler Experiments. British Poultry Science, 40: 674-680.

Huisman, J., Van der Poel, A. F. B., 1989. Comparison of Effects of Antinutritional Factors (ANFs) in Different Animal Species. In: Huisman, J., Van der Poel, T. F. B., Liener, I. E. (eds.): Recent Advances of Research in Antinutritional Factors in Legume Seeds. Pudoc Wageningen, The Netherlands, pp. 317-327.

Jakob, J., 2015. Feeding Chickpeas to Poultry. College of Agriculture, Food and Environment, Cooperative Extension Service, University of Kentucky

Katogianni, I., Zoiopoulos, P. E., Adamidis, C., Fegeros, K., 2008. Substituting Chickpeas for Soybeans in Diets for Broilers Fattened According to the European Community Organic Regime. Arch.Geflügelk., 72 (4): 152-156.

Kaya, İ., Yalçın, S., 1999. Baklagil tane yemleri ve ruminant rasyonlarında kullanımı, Lalahan Hayvancılık Araştırma Enstitüsü Dergisi, 39 (1): 101-114.

Kishor, K., David, J., Tiwari, S., Singh, A., Rai, B.S., 2017. Nutritional composition of chickpea (Cicer arietinum L.). Milk International Journal of Chemical Studies, 5 (4): 1941-1944.

Mahjoub, S.M.H., Ahmed, M. E., 2016. Effect of partial replacement of soaked chickpea seeds (Cicer Arietinum L.) for groundnut cake on broiler performance, Some Blood Biochemical Parameters and Carcass Characteristics. U. of K. J. Vet. Med. Anim. Prod., 6 (1): 33-42.
Miller, H. M., Lodebo, B., Holmes, J. H. G., 1991. Chickpeas, mung beans and pigeon peas for broilers. In: Recent Advances in Animal Nutrition in Australia (David P. and Farrell J. D., Eds). University of New England, Armidale, pp: 25A.

Mudgett, R.E., 1989. Microwave food processing. Food Technology, 1: 117-126.

Obregón, J. F., Bell, C., Iliana Elenes, A., Estrada, A., Portillo, J. J., Ríos F. G., 2012. Effect of discarded chickpea (Cicer arietinum L.) cooking on the productive response and carcass yield of japanese quail (Coturnix coturnix japonica) at the fattening stage. Cuban Journal of Agricultural Science, 46 (2): 169.

Özdemir, F., Gölükcü, M., Topuz, A., 2003. Yer fistığının (Arachis hypogaea) bazı fiziksel ve kimyasal özellikleri ve fistık kavurmada mikrodalga uygulamasının yağ asitleri bileşimi üzerine olan etkisi. G1da, 28 (1): 39-45.

Perez-Maldonado, R.A, Mannion, P.F, Farrell, D.J. 1999. Optimum inclusion of field peas, faba beans, chick peas and sweet lupines in poultry diets. I. Chemical composition and layer experiments. Br Poult Sci., 40 (5): 667-673.

Ribeiro, R. J.M.C., Melo, P. I. M., 1990. Composition and nutritive value of chickpea. Estaçao Zootecnica Nacional Departamento De Nutriçao E Alimentaçao Fonte Boa, 107-111, 2000 Vale De Santarem, Portugal.

Saini, H. S., 1989. Activity and thermal inactivation of protease inhibitors in grain Legumes. In: Huisman, J., Van der Poel, T. F. B., Liener, I. E. (eds.): Recent advances of research in antinutritional factors in legume seeds. Pudoc Wageningen, pp: 249-253.

Sharma, H.R., Nicholson, W.G., 1975. Effects of treating faba beans with formaldehyde or volatile fatty acids on the performance of dairy calves and fistulated sheep. Canadian Journal Animal Science, 55: 705-713.

Singh, U., 1988. Antinutritional factors of chickpea and pigeonpea and their removal by processing. Plant Foods for Human Nutrition, 38: 251-261.

Sulaiman, K. M. A., 2017. Locally Grown Alternative Feed Ingredients in Turkey Diets. Oregon State University. Master of Science, Oregon, $50 \mathrm{p}$.

Şengül, A.Y., 2016. Yemlik tane nohutun japon bıldırcınlarının genel performansı ve yumurta içdış kalite özelliklerine etkisi. KSU Fen Bilimleri Enstitüsü, Doktora Tezi, Kahramanmaraş. $75 \mathrm{~s}$.

Torki, M., Karimi, A., 2007. Evaluation of dietary replacement of soybean meal by chickpea supplemented by enzymes on performance of broiler chicks. World Poultry Science Association, Proceedings of the $16^{\text {th }}$ European Symp. on Poultry Nutrition, pp: 651-654. 
Van der Poel, A. F. B., 1989. Effects of processing on antinutritional factors (ANF) and nutritional value of legume seeds for non-ruminant feeding. In: Huisman, J., Van der Poel, T. F. B., Liener, I. E. (eds.): Recent advances of research in antinutritional factors in legume seeds. Pudoc Wageningen, pp: 213-229.

Van Der Poel, A. F. B., 1990. Effect of Processing on Antinutritional Factors and Protein Nutritional Value of Dry Beans (Phaseolus vulgaris L.). A Literature Review. Animal Feed Science and Technology, 29: 179-208.

Viveros, A., Brenes, A., Elices, R., Arija, I., Canales, R., 2001. Nutritional value of raw and autoclaved kabuli and desi chickpeas (Cicer arietinum L.) for growing chickens. British Poultry Science, 42: 242-251.

Wang, N., Hatcher, D.W., Tyler R.T., Toews R., Gawalko E.J., 2010. Effect of cooking on the composition of beans (Phaseolus vulgaris L.) and chickpeas (Cicer arietinum L.). Food Research International, 43 (2): 589-594.

Williams, P., Nakkoul, H. 1983. Some new concepts of food legume quality evaluation at Icarda. Proceedings of the international workshop on faba beans, kabuli chickpeas and lentils in the 1980s., pp. 395. 